\title{
Massive milky pleural effusion
}

\author{
Rahana Aju, ${ }^{1}$ Vinod K Chaubey ${ }^{2}$
}

'Department of Internal Medicine, St Vincent Hospital, Worcester, Massachusetts, USA ${ }^{2}$ Saint Vincent Hospital, University of Massachusetts Medical School, Worcester, Massachusetts, USA

\section{Correspondence to}

Dr Rahana Aju,

rahanaaju@gmail.com

Accepted 23 February 2014

\section{DESCRIPTION}

A 53-year-old man with a history of non-Hodgkin's lymphoma (NHL) presented with worsening shortness of breath. He was diagnosed with bulky grade III follicular lymphoma 5 years ago and was in remission after receiving eight cycles of chemotherapy. The chest X-ray revealed a left-sided pleural effusion (figure 1A). During thoracentesis, chylousappearing fluid was removed (figure 1B). The pleural fluid had chylomicrons, and a high triglyceride level confirmed the presence of a chylothorax. Computed axial tomography of the chest unveiled a large soft tissue mass surrounding the descending thoracic aorta as well as multiple mediastinal lymph nodes, leading to concerns about the recurrence of lymphoma (figure 1C,D). The patient underwent video-assisted thoracic surgery, and a lymph node biopsy showed follicular lymphoma. Small-tomedium sized lymphoid cells with irregular nuclear membranes are seen on H\&E stain of the lymphoid mass (figure 1E). Immunohistochemistry showed expression of CD10, CD20, CD23 and B-cell lymphoma-2 consistent with B-cell follicular lymphoma (figure 1F). The bone marrow biopsy was normal. The patient continued to have reaccumulation of massive amounts of chylous fluid, requiring multiple thoracentesis. Thoracic duct ligation was considered, but it was technically difficult in our patient, as the mass was encasing the thoracic duct. The patient was started on a medium chain triglyceride diet. Chemotherapy was initiated. Chylothorax is an uncommon and poorly described complication of NHL remission from NHL. Our case emphasises the presence of recurrent chylothorax in NHL and challenges in management.

\section{Learning points}

- Chylothorax is caused by disruption or obstruction of the thoracic duct or its tributaries as a result of lymphomatic infiltration or external compression by lymph nodes, resulting in reflux of chyle into the pleural space. ${ }^{1}$

- The management involves treatment of the underlying lymphoma and supportive treatment for chylothorax with drainage.

- In case of refractory chylothorax, pleurodesis or pleuroperitoneal shunting might be required to prevent reaccumulation.
CrossMark

To cite: Aju R, Chaubey VK. BMJ Case Rep Published online: [please include Day Month Year] doi:10.1136/ bcr-2013-203105

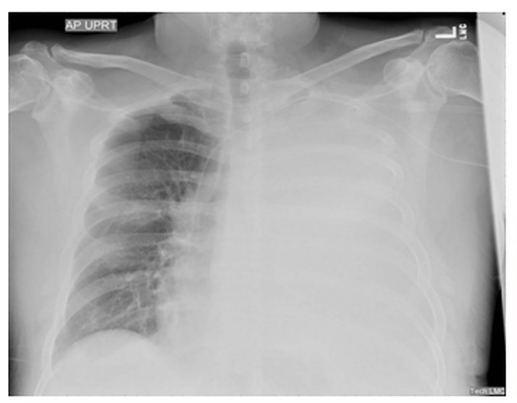

A

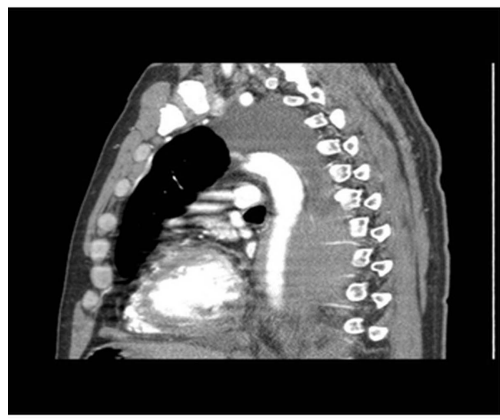

D

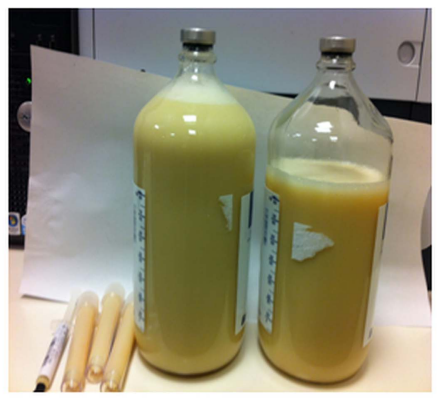

B

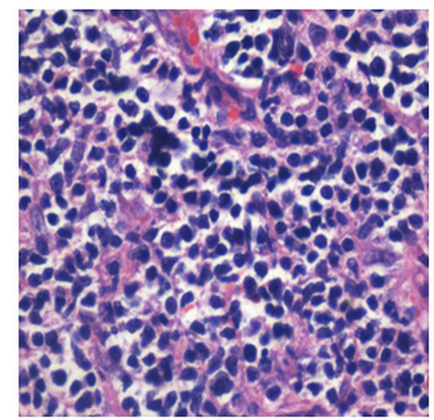

E

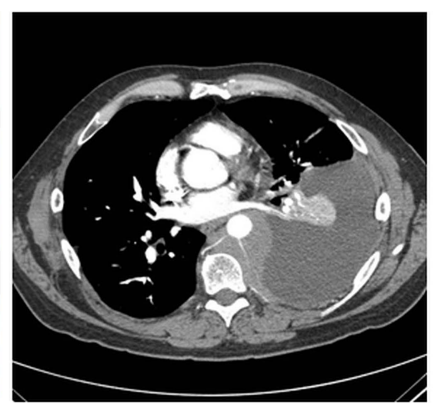

C

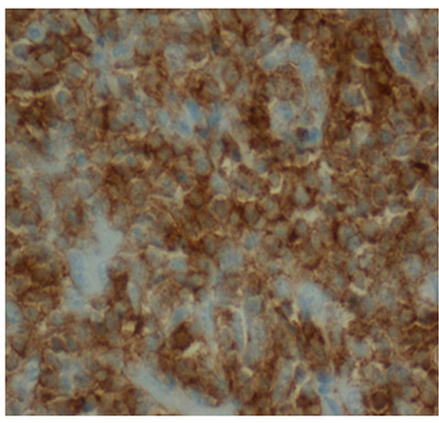

F
Figure 1 (A) Chest X-ray showing massive left-sided pleural effusion. (B) Chylous fluid drained during thoracentesis. (C and D) Contrast-enhanced computed axial tomography (CAT) of the chest showing posterior mediastinal soft tissue mass encasing the descending aorta and massive left-sided pleural effusion. (E) H\&E stain at $\times 40$ : small-to-medium sized lymphoid cells with irregular nuclear membranes. (F) CD10 immunohistochemical stain, $\times 40$ : the lymphoid cells are immunoreactive with CD10 immunostain, indicating a follicular centre cell origin 
Competing interests None.

Patient consent Obtained.

Provenance and peer review Not commissioned; externally peer reviewed.

\section{REFERENCES}

1 Doerr $\mathrm{CH}$, Allen MS, Nichols FC III, et al. Etiology of chylothorax in 203 patients. Mayo Clin Proc 2005;80:867-70.

2 O'Callaghan AM, Mead GM. Chylothorax in lymphoma: mechanisms and management. Ann Oncol 1995;6:603-7.

Copyright 2014 BMJ Publishing Group. All rights reserved. For permission to reuse any of this content visit

http://group.bmj.com/group/rights-licensing/permissions.

BMJ Case Report Fellows may re-use this article for personal use and teaching without any further permission.

Become a Fellow of BMJ Case Reports today and you can:

- Submit as many cases as you like

- Enjoy fast sympathetic peer review and rapid publication of accepted articles

- Access all the published articles

- Re-use any of the published material for personal use and teaching without further permission

For information on Institutional Fellowships contact consortiasales@bmjgroup.com

Visit casereports.bmj.com for more articles like this and to become a Fellow 